\title{
Benthic foraminiferal and isotopic patterns during the Early Eocene Climatic Optimum (Aktulagay section, Kazakhstan)
}

\author{
Arne Deprez $\left({ }^{a}\right)$, Steven Tesseur $\left({ }^{a}\right)$, Peter Stassen $\left({ }^{a}\right)$, Simon D’haenens $\left({ }^{a}\right)$, Etienne Steurbaut $\left({ }^{a, b}\right)$, Christopher King $\left({ }^{c}\right)$, \\ Philippe Claeys $\left({ }^{\mathrm{d}}\right)$ \& Robert P. Speijer $\left({ }^{\mathrm{a}}\right)$
}

\author{
( $\left.{ }^{\mathrm{a}}\right)$ Department of Earth and Environmental Sciences, KU Leuven, Celestijnenlaan 200E, B-3001 Leuven, Belgium E-mail; arne.deprez@ees.kuleuven.be \\ (b) Department of Paleontology, Royal Belgian Institute of Natural Sciences, Vautierstraat 29, B-1000 Brussels, Belgium \\ (c) 316A Park Rd., Bridport DT6 5DA, United Kingdom \\ (d) Earth System Science, Vrije Universiteit Brussel, Pleinlaan 2, B-1050 Brussels, Belgium.
}

Document type: Short note.

Manuscript history: received 15 May 2014; accepted 30 May 2014; editorial responsibility and handling by Gerald R. Dickens \& Valeria Luciani.

KEY WORDS: benthic foraminifera, Eocene, Kazakhstan, oxygen deficiency, paleoecology, stable isotope, trophic conditions

The early Eocene is characterized by long-term global warming culminating in the Early Eocene Climatic Optimum (EECO; Zachos et al., 2001; 2008). During this time interval, of which previously only the Paleocene Eocene Thermal Maximum was intensively studied, the Peri-Tethys was connected to the Arctic and Atlantic Oceans by north-south and east-west trending seaways (Akhmetiev, 2011). The Aktulagay section in Kazakhstan provides an expanded record of the middle Ypresian (NP11-13, 54-50 Ma; King et al., 2013), including the EECO. It features a correlatable series of sapropel beds, observed throughout the Peri-Tethys (Oberhänsli and Beniamovski, 2000). In order to unravel paleoenvironmental changes, we carried out quantitative faunal studies and stable isotopic $(\mathrm{C}, \mathrm{O})$ investigations on excellently preserved foraminiferal assemblages.

The period from 54 to $53 \mathrm{Ma}$ (NP11 to lower NP12; Alashen Formation) is characterized by a diverse assemblage of deep outer neritic benthic foraminifera, with common Pulsiphonina prima and Paralabamina lunata. Coupled negative carbon and oxygen isotope excursions point to hyperthermals occurring during this time interval, but these are not evident from the faunal or sedimentological record. The initially (54 Ma) well-ventilated oligo- to meso-trophic sea floor conditions gradually change to more eutrophic and oxygen-limited. This gradual onset culminates in permanent stratification in the sapropel-bearing unit at 53-52 Ma (middle NP12; Aktulagay B1 unit), with the dominance of Anomalinoides acutus and Bulimina aksuatica. The absence of ostracods and abundance of hematitic concretions are consistent with this interpretation. Rising $\delta^{13} \mathrm{C}_{\text {endobenthic indicates }}$ migration of endobenthic species to the sediment-water interface, indicating oxygen limitation during deposition of the Aktulagay B1 unit. Benthic foraminiferal assemblages dominated by Epistominella minuta at $\sim 52-50 \mathrm{Ma}$ (top NP12NP13; Aktulagay B2 unit) indicate a highly seasonal food supply and episodic disruption of stratification. Dinoflagellate blooms and Acarinina isotope values at $20.25 \mathrm{~m}$ indicate lower salinity (lower $\delta^{18} \mathrm{O}$ ) and higher productivity (higher $\delta^{13} \mathrm{C}$ ), possibly due to riverine input. This coincides with the peak of the EECO, as indicated by its position close to the base of $\mathrm{NP} 13$ and rising $\delta^{13} \mathrm{C}_{\text {foram }}$ values.

The long-term change from oligo-mesotrophic (Alashen Formation) to more eutrophic (Aktulagay B2 unit) coincides with a transition from a paratropical to a monsoonal (seasonal) climate, based on land vegetation changes (Akhmetiev \& Beniamovskii, 2009). This climate change is linked to the formation of a land barrier in the Pripyat strait.

Although it is tempting to link the observed patterns to climate change, we cannot currently exclude that changing paleogeography and variable connections between the PeriTethys and the Tethys, Atlantic and the Arctic Oceans largely determined the long-term period of dysoxia and anoxia during deposition of the sapropel beds at the Peri-Tethyan seafloor.

\section{REFERENCES}

Akhmetiev M.A. (2011) - Problems of Paleogene stratigraphy and paleogeography in the middle latitudes of Eurasia. Russ. Geol. Geophys., 52, 10, 1075-1091, doi:10.1016/j.rgg.2011.09.004.

Akhmetiev M.A. \& Beniamovskii V.N. (2009) - Paleogene floral assemblages around epicontinental seas and straits in Northern Central Eurasia: proxies for climatic and paleogeographic evolution. Geol. Acta, 7, 1-2, 297-309, doi:10.1344/105.000000278.

King C., Iakovleva A.I., Steurbaut E., Heilmann-Clausen C. \& Ward D.J. (2013) - The Aktulagay section, west Kazakhstan: a key site for northern mid-latitude Early Eocene stratigraphy. Stratigraphy, 10, 171-209.

Oberhänsli H. \& Beniamovski V.N. (2000) - Dysoxic bottom water events in the Peri-Tethys during the late Ypresian: A result of changes in the evaporation/precipitation balance in adjacent continental regions. GFF, 122, 1, 121-123. 
Zachos J.C., Pagani M., Sloan L.C., Thomas E. \& Billups K. (2001) - Trends, rhythms and aberrations in global climate $65 \mathrm{Ma}$ to present. Science, 292, 686-693, doi:10.1126/science.1059412.
Zachos J.C, Dickens G.R. \& Zeebe R.E. (2008) - An early Cenozoic perspective on greenhouse warming and carboncycle dynamics. Nature, 451, 279-283, doi:10.1038/nature06588. 